\title{
Büyüme Korkusu ile Erken Dönem Uyumsuz Şemalar ve Algılanan Ebeveynlik Biçimleri Arasındaki İlişsilerin İncelenmesi
}

\author{
Investigation of the Relationships Between Growth Fear, Early Maladaptive Schemas \\ and Perceived Parenting Styles
}

\author{
Doç. Dr. Melis Seray ÖZDEN YILDIRIM ${ }^{(1)}$, Dr. Öğr. Üyesi Nida ATEŞi22
}

\begin{abstract}
$\ddot{\mathbf{O} z}$
$\mathrm{Bu}$ çalışmanın amacı büyüme korkusu ile erken dönem uyumsuz şemalar ve algılanan ebeveynlik biçimleri arasındaki ilişkilerin incelenmesidir. Çalışma 18-35 yaş arasında olan ve İstanbul'da yaşayan 400 kişilik bir örneklem grubu ile yapılmıştır. Demografik Bilgi Formu, Büyüme Korkusu Ölçeği (BKÖ), Young Şema Ölçeği Kısa Formu (YŞÖ-KF3) ve Young Ebeveynlik Ölçeği kullanılmıştır. Çalışma sonucunda büyüme korkusu ile duygusal yoksunluk, başarısızlık, karamsarlık, sosyal izolasyon/güvensizlik, duyguları bastırma, iç içe geçme/bağımlılık, ayrıcalıklılık/yetersiz özdenetim, terkedilme, kusurluluk, tehditler karşısında dayanıksızlık ve yüksek standartlar şemaları arasında pozitif yönde anlamlı ilişkiler olduğu saptanmıştır. Algılanan ebeveyn biçimleri bakımından ise büyüme korkusu ile cezalandırıcı, kötümser/endişeli, aşırı izin verici/sınırsız, aşırı koruyucu/evhamlı, küçümseyici/kusur bulucu olarak algılanan babaya ilişkin ebeveynlik biçimleri arasında pozitif yönde anlamlı ilişkiler bulunmuştur. Büyüme korkusu ile cezalandırıcı, aşırı koruyucu/evhamlı, duygusal bakımdan yoksun bırakıcı, küçümseyici/kusur bulucu ve kuralcı/kalıplayıcı olarak algılanan anneye ilişkin ebeveynlik biçimleri arasında da pozitif yönde anlamlı ilişkiler bulunmuştur. Özetle, genel olarak anne ve baba tarafından algılanan ebeveynliğin büyüme korkusunu etkilediği ve iki şema (kendini feda, cezalandırıcılık) dışında erken dönem uyumsuz şemalarla büyüme korkusunun ilişkili oldukları sonucuna ulaşılmıştır.
\end{abstract}

Anahtar Kelimeler: Büyüme korkusu, ebeveynlik biçimleri, erken dönem uyumsuz şemalar

Makale Türü: Araştırma

\begin{abstract}
The aim of this study was to examine the relationships between growth fear, early maladaptive schemas and perceived parenting styles. The sample group of the study was 400 adults aged between 18-35, living in Istanbul. Demographical Information Form, Growth Fear Scale, Young Schema Questionnaire Short Form-3 and Young Parenting Inventory were used. The results of the study indicated that there were positive significant relationships between growth fear and emotional deprivation, failure, pessimism, social isolation/mistrust, emotional inhibition, enmeshment/dependence, entitlement/insufficient selfcontrol, abandonment, defectiveness, vulnerability to harm and unrelenting standards schemas. There were positive significant relationships between growth fear and punitive, pessimistic/worried, extreme permissive/unlimited, overprotective/anxious, belittling/criticizing parenting styles on the father forms of the scales. There were positive significant relationships between growth fear and punitive, overprotective/anxious, emotionally depriving, belittling/criticizing and normative parenting styles on the mother forms of the scales. In summary, it was concluded that parenting perceived by the mother and father, in general, affects the growth fear and that the growth fear is related to early maladaptive schemes, except for two schemes (self-sacrifice and punitiveness).
\end{abstract}

Keywords: Growth fear, parenting styles, early maladaptive schemas

Paper Type: Research

\footnotetext{
1 İstanbul Kültür Üniversitesi Fen Edebiyat Fakültesi, m.ozden@iku.edu.tr.

2 İstanbul Kültür Üniversitesi Fen Edebiyat Fakültesi, n.ates@iku.edu.tr.
}

Atıf için (to cite): Özden-Yıldırım, M. S. ve Ateş, N. (2020). Büyüme korkusu ile erken dönem uyumsuz şemalar ve algilanan ebeveynlik biçimleri arasindaki ilişkilerin incelenmesi. Afyon Kocatepe Üniversitesi Sosyal Bilimler Dergisi, 22 (4), 872-884. 


\section{Giriş}

Günümüzde hızlı endüstrileşmeyle beraber değişen hayat şartları bireylerin yaşam dönemleri üzerinde de belirgin değişikliklere sebep olmaktadır. İnsan ömrünün uzamasıyla beraber kişilerin bulundukları yaşa dair kendilerinden beklenen rollerde de farklılıklar gözlenmeye başlamıştır. Bunlardan en belirgin olanı da 18-29 yaş arasındaki bireylerden beklenen yetişkinliğe dair rollerde görülen değişikliklerdir. Bunlar özellikle eğitimini tamamlamak, evlenmek, çocuk sahibi olmak olarak sayılabilir (Atak ve Çok, 2010). Fakat günümüzde genç yetişkinlik döneminde olması beklenen bu bireylerin, kendilerinden beklenen rolleri tam olarak gerçekleştiremedikleri hatta gerçekleştirmeye karşı da bir çaba sergilemedikleri gözlenmektedir.

Literatürde "Beliren Yetişkinlik" olarak da tanımlanan bu dönemde bireyler ne henüz çocukluğun bağımlılığını tamamen bırakmış ne de henüz yetişkin olma sorumluluğunu tümüyle kabul etmişlerdir (Arnett, 2000; Atak ve Çok, 2010). Bu dönemin sonunda kişi, planlar yaparak ve bu planlara göre kararlarını istediği yönde değiştirerek yetişkin kimliğini bulmaktadır. Arnett'in (2000) ileri sürdüğü beliren yetişkinlik döneminde olduğu gibi, bir kişinin 18-25 hatta 28-29 yaşlarını geçtiği halde kendisini henüz bir yetişkin olarak tanımlayamaması durumunda da yeni bir kavram olarak "Büyüme Korkusu" ile karşılaşılmaktadır (Ateş ve Özden Yıldırım, 2018).

Büyüme korkusu uzamış bir ergenlik döneminin temsili gibidir ancak bireyler ergenlerden farklı olarak fiziksel gelişimlerini tamamlamış ve 18 yaşından büyük olmanın getirdiği yasal haklara da sahip durumda (Doğan ve Cebioğlu, 2011) olmalarına rağmen yetişkinliğin getirdiği sorumlulukları yerine getirmekten kaçındıklarından, bir duygusal ve sosyal ikilemi ifade etmektedir. Genellikle 18-35 yaş arasında yaşanılan bu dönemde bireyler sosyal-duygusal yalnızlık, romantik ilişkiyi sürdürmede zorlanma, evliliğe karşı olumsuz tutumlar sergileme ve bağımsız yaşama hazırlık ve sorumluluğu içselleştirmede zorlanma konularında problemler yaşamaktadırlar (Ateş ve Özden Yıldırım, 2018). Bu kişilere genel olarak bakıldığında başarılı bir ayrıșma bireyleșme süreci gerçekleștiremedikleri görülmektedir, çünkü başarılı bir ayrı̧̧ma bireyleşme için, özerklik duygusuna gereksinim vardır. $\mathrm{Bu}$ da benliğin oluşumu ile bağlantılı olarak, bireyin ilk sosyalleştiği yer olan aile sisteminin içerisinde başlamaktadır. Bu durum da aile içi ilişkilerin önemine dikkat çekmektedir (Yavuzer, 2011; Özden, 2013). Ruhsal olarak sağlıklı ve topluma uyumlu birer yetişkin olabilmek için çocukluk döneminde temel duygusal gereksinimlerinin karşılanması gerekmektedir (Young, Klosko ve Weishaar, 2003; Soygüt, Çakır ve Karaosmanoğlu, 2008).

Bowlby'nin (1973) kuramından yola çıkan şema odaklı yaklaşımlar da temelde bağlanma figürleriyle olan etkileşimlere dayanmaktadır. Bu etkileşimler doğrultusunda söz edilen diğerlerine güvenli bağlanma, ayrışma ve bireyleşme, özerklik, yetkinlik, kimlik gelişimi, duyguların ve ihtiyaçların ifade edilmesi gibi temel duygusal gereksinimler de karşılanabilmektedir (Young, Klosko ve Weishaar, 2003). Erken dönemde ebeveynlerle kurulan yeterli ve doyurucu duygusal bağlar, bireylerin çevresine uyum sağlamasını kolaylaştırırken, ileriki yaşantılarında sosyal ve duygusal problemler yaşama olasılıklarını da azaltmaktadır (Sable, 2008). Şemaların kökeninde bu erken dönem yaşantılar önem taşımaktadır; uyumsuz şemaların temelinde de örseleyici çocukluk yaşantıları bulunmaktadır. Young, Klosko ve Weishaar (2003) tarafindan, erken dönem uyumsuz şemalar, çocukluk veya ergenlik dönemlerinde başlayan, yaşam boyu kendini tekrarlayan, kendilik yıkıcı duygusal ve bilişsel örüntüler olarak tanımlanmaktadır. Erken dönem uyumsuz şemalar, kişinin hayatta kalması için savaşan ancak kişiye acı veren, değiştirilmesi çok zor olan örüntülerdir (Young ve Klosko, 2011; Hoffart, 2012) ve çocukluktaki beş çekirdek duygusal ihtiyacın karşılanmaması sebebiyle meydana gelmektedir. Şema alanları, karşılanmamış bu duygusal ihtiyaçların beş kategorisi içinde gruplanıp oluşturulmuştur (Young, Klosko ve Weishaar, 2003). Bu 5 şema alanı ve 18 erken dönem uyumsuz şeması şu şekilde sıralanmıştır: ayrılma/dışlanma alanı (terk edilme, 
güvensizlik, duygusal yoksunluk, kusurluluk ve sosyal izolasyon şemaları), zedelenmiş özerklik alanı (bağımlılık, dayanıksızlık, yapışıklık ve başarısızlık şemaları), başkaları yönelimlilik alanı (boyun eğicilik, kendini feda ve onay arayıcılık şemaları), zedelenmiş sınırlar alanı (haklılık ve yetersiz özdenetim şemaları), aşırı duyarlılık ve baskılama alanı (karamsarlık, duyguları bastırma, yüksek standartlar ve cezalandırıcılık şemaları) (Young, Klosko ve Weishaar, 2003).

Şema kuramına göre bilişsel şemalar ile bireylerin algıladıkları ebeveynlik biçimleri ilişkilidir (Young, Klosko ve Weishaar 2003; Soygüt ve Çakır, 2009). Ayrıca alanyazında ebeveynlik biçimleri ile psikolojik belirtilerin ilişkili olduğunu gösteren araştırma bulguları bulunmaktadır (Sheffield ve vd. 2006; Soygüt ve Çakır, 2009). Bunun yanı sıra algılanan ebeveynlik biçimleriyle depresif belirtiler arasındaki ilişkide erken dönem uyumsuz şemaların aracı rolü bulunmaktadır (Harris ve Curtin, 2002). Eleştirel, reddedici, aşırı koruyucu ya da ihmalkâr olma gibi olumsuz ebeveynlik biçimleri kişilerin, kendilerinin yetersiz ve değersiz olduğunu düşünmeleri gibi olumsuz temel inançlar geliştirebilmelerine sebep olabilmektedir (Başbuğ, Cesur ve Batıgün, 2017). Bu durum da bireylerin diğerleri ile sağlıklı ilişki kurmasını engelleyebilmektedir. Bu kişilerin aile ilişkilerine bakıldığında ebeveynlerinden sağlıklı bir ayrışma süreci gerçekleştirememiş ve bireyleşememiş oldukları görülmektedir. Özellikle son yıllarda sağlıklı bir ayrışma ve bireyleşme süreci gerçekleştiremeyen 25 yaşından büyük ve herhangi bir ruhsal bozukluğu olmayan kişilerin yetişkin olmaya karşı takındıkları olumsuz tutumlar ve bu tutumları dolayısıyla da yaşadıkları sorunlar ön plana çıkmaktadır (Ateş ve Özden Yıldırım, 2018).

Bu çalışmada da büyüme korkusu ile erken dönem uyumsuz şemalar ve algılanan ebeveynlik biçimleri arasındaki ilişkinin incelenmesi amaçlanmıştır. Çalışma, şemalarla algılanan ebeveynlik biçimlerini son y1llarda önem kazanan bir kavram olan "büyüme korkusu" ile ele alması hem alanyazına katkıda bulunması hem de uygulama alanında genç yetişkinlerin yaşadıkları sosyal problemlerin kökenlerinin de daha iyi anlaşılmasını sağlamak bakımından önem taşımaktadır.

\section{Yöntem}

\section{1. Örneklem}

Çalışmanın örneklemi, ulaşılabilir örneklem (convenience sampling) yöntemi ile ulaşılan, 18-35 yaş aralığında bulunan, İstanbul'da yaşayan, 200 kadın ve 200 erkek olmak üzere toplam 400 kişiden oluşmaktadır. Yaş ortalaması 24.86'dır (ss=3.95). Tablo 1'de örneklem grubunun demografik özelliklerine göre dağılımı sunulmuştur.

Tablo 1. Örneklem grubunun demografik özelliklerine göre dağılımı

\begin{tabular}{llcc}
\hline & & $F$ & $\%$ \\
\hline Cinsivet & Kadın & 200 & 50 \\
& Erkek & 200 & 50 \\
\hline \multirow{2}{*}{ Gelir düzevi } & Düsük & 70 & 17.5 \\
& Orta & 217 & 54.3 \\
& Yüksek & 113 & 28.2 \\
\hline Calıșma durumu & Öğrenci/Calısmıvor & 215 & 53.8 \\
& Calıșyor & 185 & 46.3 \\
\hline \multirow{2}{*}{ Ẹ̆̆itim } & Lise ve altı & 235 & 58.8 \\
& Lisans ve üstü & 165 & 41.3 \\
\hline
\end{tabular}

Tablo 1'de katılımcıların cinsiyet, çalışma durumu, eğitim ve gelir düzeyi değişkenlerine ait frekans ve yüzde değerleri verilmiştir. Katılımcıların gelir düzeyleri incelendiğinde, $\% 17.5$ 'i düşük, \%54.3'ü orta ve \%28.2'si yüksek düzeydedir. Çalışma durumları incelendiği zaman \%53.8'i öğrenci ve/veya çalışmamakta, \%46.3'ü çalışmaktadır. Eğitim durumu olarak katılımcıların \% 58.8'i lise ve altı düzeyde, \%41.3’ü lisans ve üstü düzeyde eğitime sahiptir. 


\subsection{Veri Toplama Araçları}

Veri toplama aracı olarak; Demografik Bilgi Formu, Büyüme Korkusu Ölçeği (BKÖ), Young Şema Ölçeği Kısa Formu (YŞÖ-KF3), Young Ebeveynlik Ölçeği kullanılmıştır.

\subsubsection{Demografik Bilgi Formu}

Araştırmacılar tarafından hazırlanan demografik bilgi formunda katılımcıların cinsiyeti, yaşı, eğitim durumu, çalışma durumu, gelir düzeyine dair sorular yer almıştır.

\subsubsection{Büyüme Korkusu Ölçeği (BKÖ)}

BKÖ, 18-35 yaş arasındaki kişilerin normal gelişim süreçleri içinde büyümek ve yetişkin olmakla ilgili korkularını ölçmek amacıyla Ateş ve Özden Yıldırım (2018) tarafından geliştirilmiştir. Ölçek, cevapların "Kesinlikle Katılıyorum (5)", ile "Kesinlikle Katılmıyorum (1)" arasında değişen 5'li likert tipi bir ölçek şeklinde düzenlenmiştir. AFA sonucunda SosyalDuygusal Yalnızlık, Romantik İlişkileri Sürdürmede Zorlanma, Evlenmeye Karşı Olumsuz Tutumlar, Bağımsız Yaşama Hazırlık ve Sorumluluğu İçselleştirmede Zorlanma olmak üzere 4 faktörden oluşan bir yapı elde edilmiştir. DFA sonucuna göre maddelerin faktör yüklerinin .51 ile .87 arasında değiştiği görülmüştür. Ölçeğin 7., 9. ve 11. maddeleri ters yönde puanlanmaktadır. Orijinal çalışmada ölçeğin tümü için iç tutarlılık katsayısı .75'tir (Ateş ve Özden Yıldırım, 2018). Bu çalışmada Cronbach Alfa katsayısı sosyal duygusal yalnızlık alt boyutu için .59, romantik ilişkileri sürdürme alt boyutu için .74, evlenmeye karş1 olumsuz tutumlar alt boyutu için .78, bağımsız yaşama hazırlık alt boyutu için .46 ve ölçeğin bütünü için .76 olarak bulunmuştur.

\subsubsection{Young Şema Ölçeği Kısa Formu (YŞÖ-KF3)}

Jeffrey Young (1999) tarafından geliştirilen ölçekte 5 şema alanı altında 18 boyut bulunmaktadır. 90 maddeden oluşan ölçekte her bir madde 6'l1 likert üzerinde " $1=$ Benim için tamamı ile yanlış" ile " $6=$ Beni mükemmel şekilde tanımlıyor" seçenekleri arasında derecelendirilmektedir.

Ölçeğin Türkçe adaptasyonu Soygüt, Karaosmanoğlu ve Çakır (2009) tarafindan yapılmıştır ve duygusal yoksunluk, başarısızlık, karamsarlık, sosyal izolasyon/güvensizlik, duyguları bastırma, onay arayıcılık, iç içe geçme/bağımlılık, ayrıcalıklılık/yetersiz özdenetim, kendini feda, terk edilme, cezalandırılma, kusurluluk, tehditler karşısında dayanıksızlık ve yüksek standartlardan oluşan 14 faktörlü bir yapı elde edilmiştir. Alt ölçekler için iç tutarlılık katsayıları $\alpha=.63-.80$ arasında değişmektedir (Soygüt, Karaosmanoğlu ve Çakır, 2009). Bu çalışmada ölçeğin Cronbach Alfa katsayısı $\alpha=.76$ olarak bulunmuştur. Ölçeğin puanlaması için, her 14 şema özelinde ayrı olarak " $1=$ Benim için tamamı ile yanlış" ile " $6=$ Beni mükemmel şekilde tanımlıyor" seçenekleri arasındaki puanlar toplamı alınarak derecelendirme yapılmaktadır (Soygüt, Karaosmanoğlu ve Çakır, 2009).

\subsubsection{Young Ebeveynlik Ölçeği}

Young (1994) tarafindan geliştirilen Young Ebeveynlik Ölçeği (YEBÖ)'nin Türk örneklemi için geçerlilik ve güvenirliği Soygüt, Çakır ve Karaosmanoğlu (2008) tarafından yapılmıştır. İç tutarlık katsayıları YEBÖ-A formunda $\alpha=.53-.86$, YEBÖ-B formunda ise $\alpha=$ .61 - .88 arasında değişmektedir. Anne ve Baba formları için kuralcı/kalıplayıcı, küçümseyici/kusur bulucu, duygusal bakımdan yoksun bırakıcı, sömürücü/istismar edici, aşırı koruyucu/evhamlı, koşullu/başarı odaklı, aşırı izin verici/sınırsız, kötümser/endişeli, cezalandırıcı ve değişime kapalı/duygularını bastıran ebeveynlikten oluşan 10 faktörlü ortak bir yapı saptanmıştır (Soygüt, Çakır ve Karaosmanoğlu, 2008). Bu çalışmada ölçeğin Cronbach Alfa katsayısı anne formu için .73, baba formu için .65 olarak bulunmuştur. Ölçeğin değerlendirilmesi için, 10 ayrı ebeveynlik türü özelinde " $1=$ Tamamı ile yanlış", " $6=$ Ona tamamı ile uyuyor" seçenekleri arasında kişilerin anne ve babalarını değerlendirmelerine dair sonuçların toplamı alınarak gerçekleştirilir. 


\subsection{Veri Toplama Süreci ve Verilerin Analizi}

Araştırmaya katılmak için gönüllü olan kişilere, kendilerini değerlendirmeleri için öz bildirim anketleri uygulanmıştır. Katılımcılara bilgilendirilmiş onam verilmiştir. Veriler üniversite öğrencilerine okulda ve çeşitli iş yerlerinde çalışan kişilere çalıştıkları kurumlarda fiziki olarak ölçek kağıtlarının sunulmasıyla toplanılmıştır. Katılım karşılığında herhangi bir teşvik verilmemiştir. Çalışmada ilişkisel tarama modeli kullanılmıştır. İlişkisel tarama modeli, birden çok değişken arasındaki birlikte değişimin derecesini belirlemek için kullanılmaktadır (Karasar, 2016). Verilerin analizi SPSS 21.0 paket programında yapılmıştır. Verilerin normal dağılım analizi için Shapiro-Wilk uygulanmıştır. Yapılan normal dağılım analizinde verilerin normal dağılım gösterdiği görülmüş $(\mathrm{p}>.05)$ ve parametrik analizler yapılmıştır. Verilerin analizinde betimleyici istatistiki analizler ve Pearson Korelasyon Analizi kullanılmıştır. Bu çalışma için anlamlılık düzeyi .05'tir.

\section{Bulgular}

Araştırma değişkenlerinden büyüme korkusu ve diğer değişkenlere ait betimleyici bilgiler Tablo 2'de sunulmuştur.

Tablo 2. Araştırma değişkenlerine ait ortalamalar ve standart sapmalar $(\mathrm{N}=400)$

\begin{tabular}{|c|c|c|}
\hline & $\overline{\mathrm{X}}$ & Ss \\
\hline \multicolumn{3}{|l|}{ Büyüme korkusu } \\
\hline Sosyal duygusal yalnızlık & 7.21 & 2.53 \\
\hline Romantik ilişkiyi sürdürmede zorlanma & 11.52 & 4.18 \\
\hline Evliliğe karşı olumsuz tutum & 7.72 & 3.19 \\
\hline Bağımsız yaşama hazırlık ve sorumluluğu içselleştirmede zorlanma & 7.74 & 2.58 \\
\hline \multicolumn{3}{|l|}{ Babaya ilişkin algılanan ebeveynlik biçimleri } \\
\hline Değişime kapalı/duyguları bastıran (baba) & 10.14 & 3.85 \\
\hline Cezalandirıcı (baba) & 9.32 & 3.8 \\
\hline Kötümser/endişeli (baba) & 7.57 & 4.01 \\
\hline Aşırı izin verici/sınırsız (baba) & 11.85 & 6.16 \\
\hline Koşullu/başarı odaklı (baba) & 17.18 & 6.13 \\
\hline Aşırı koruyucu/evhamlı (baba) & 19.68 & 6.59 \\
\hline Sömürücü/istismar edici (baba) & 10.19 & 6.73 \\
\hline Duygusal bakımdan yoksun bırakıcı (baba) & 23.27 & 10.78 \\
\hline Küçümseyici/kusur bulucu (baba) & 15.59 & 8.75 \\
\hline Kuralcı/kalıplayıcı (baba) & 34.63 & 21.01 \\
\hline \multicolumn{3}{|l|}{ Anneye ilişkin algılanan ebeveynlik biçimleri } \\
\hline Değişime kapalı/duyguları bastıran (anne) & 8.31 & 3.12 \\
\hline Cezalandırıcı (anne) & 8.88 & 3.53 \\
\hline Kötümser/endişeli (anne) & 7.99 & 6.41 \\
\hline Aşırı izin verici/sınırsız (anne) & 11.05 & 5.58 \\
\hline Koşullu/başarı odaklı (anne) & 17.26 & 6.06 \\
\hline Aşırı koruyucu/evhamlı (anne) & 21.96 & 7.05 \\
\hline Sömürücü/istismar edici (anne) & 8.54 & 4.49 \\
\hline Duygusal bakımdan yoksun birakıcı (anne) & 19.02 & 10.4 \\
\hline Küçümseyici/kusur bulucu (anne) & 13.51 & 6.76 \\
\hline Kuralcı/kalıplayıcı (anne) & 31.73 & 12.04 \\
\hline \multicolumn{3}{|l|}{ Erken Dönem Uyumsuz Şemalar } \\
\hline Duygusal yoksunluk & 8.56 & 4.73 \\
\hline Başarısızlık & 11.83 & 5.24 \\
\hline Karamsarlık & 11.94 & 6.29 \\
\hline Sosyal izolasyon/güvensizlik & 16.39 & 6.33 \\
\hline Duyguları bastırma & 12.17 & 7.83 \\
\hline Onay arayıcılık & 21.6 & 12.61 \\
\hline İç içe geçme/bağımlılık & 16.13 & 6.57 \\
\hline Ayrıcalıklılık/yetersiz özdenetim & 25.75 & 7.14 \\
\hline Kendini feda & 16.05 & 6.88 \\
\hline
\end{tabular}


Terkedilme

Cezalandırıcılık

Kusurluluk

Tehditler karşısında dayanıksızlık

Yüksek standartlar

\begin{tabular}{cc}
9.37 & 6.96 \\
20.65 & 5.42 \\
9.62 & 3.96 \\
11.42 & 4.63 \\
9.33 & 4.23 \\
\hline
\end{tabular}

Büyüme korkusu ile erken dönem uyumsuz şemalar arasındaki ilişkilere dair Pearson Korelasyon Analizi sonuçları Tablo 3'te paylaşılmıştır.

Tablo 3. Büyüme korkusu ile erken dönem uyumsuz şemalar arasındaki ilişkiye dair pearson korelasyon analizi sonuçları $(\mathrm{N}=400)$

\begin{tabular}{|c|c|c|c|c|c|}
\hline $\begin{array}{l}\text { Erken Dönem } \\
\text { Uyumsuz Şemalar }\end{array}$ & $\begin{array}{c}\text { Büyüme } \\
\text { Korkusu } \\
\text { Sosyal } \\
\text { Duygusal } \\
\text { Yalnılik Alt } \\
\text { Boyutu }\end{array}$ & $\begin{array}{c}\text { Büyüme } \\
\text { Korkusu } \\
\text { Romantik } \\
\text { İlişkiyi } \\
\text { Sürdürmede } \\
\text { Zorlanma Alt } \\
\text { Boyutu }\end{array}$ & $\begin{array}{c}\text { Büyüme } \\
\text { Korkusu } \\
\text { Evliliğe } \\
\text { Karşı } \\
\text { Olumsuz } \\
\text { Tutum Alt } \\
\text { Boyutu }\end{array}$ & $\begin{array}{c}\text { Büyüme } \\
\text { Korkusu } \\
\text { Bağımsız } \\
\text { Yaşama } \\
\text { Hazırlık ve } \\
\text { Sorumluluğu } \\
\text { İçselleştirmede } \\
\text { Zorlanma Alt } \\
\text { Boyutu }\end{array}$ & $\begin{array}{c}\text { Büyüme } \\
\text { Korkusu } \\
\text { Toplam } \\
\text { Puan }\end{array}$ \\
\hline 1.Duygusal yoksunluk & $.34 *$ & $.19 *$ & .08 & $.14^{*}$ & $.29 *$ \\
\hline 2.Başarısızlık & $.25^{*}$ & $.13 *$ & $.13^{*}$ & $.25^{*}$ & $.27 *$ \\
\hline 3.Karamsarlık & $.28 *$ & $.13^{*}$ & $.10^{*}$ & $.22 *$ & $.26^{*}$ \\
\hline $\begin{array}{l}\text { 4.Sosyal } \\
\text { izolasyon/güvensizlik }\end{array}$ & $.45^{*}$ & $.18 *$ & $.17 *$ & $.20 *$ & $.36^{*}$ \\
\hline 5.Duyguları bastırma & $.16^{*}$ & $.20 *$ & $.11 *$ & $.15^{*}$ & $.24 *$ \\
\hline 6.Onay arayıcılık & .01 & .04 & .0 & $.16^{*}$ & .08 \\
\hline $\begin{array}{l}\text { 7.İç içe } \\
\text { geçme/bağımlılık }\end{array}$ & $.22 *$ & $.15^{*}$ & $.18^{*}$ & $.24 *$ & $.29 *$ \\
\hline $\begin{array}{l}\text { 8.Ayricalıklılık/yetersiz } \\
\text { özdenetim }\end{array}$ & $.10^{*}$ & $.25^{*}$ & $.26^{*}$ & $.37 *$ & $.38^{*}$ \\
\hline 9.Kendini feda & .09 & .04 & .0 & .04 & .07 \\
\hline 10.Terkedilme & $.18 *$ & .05 & .06 & $.14^{*}$ & $.15^{*}$ \\
\hline 11.Cezalandırıcılık & .07 & .05 & -.05 & .02 & .03 \\
\hline 12.Kusurluluk & $.31 *$ & $.29 *$ & $.20 *$ & $.28 *$ & $.41 *$ \\
\hline $\begin{array}{l}\text { 13.Tehditler karşısında } \\
\text { dayanıksızlık }\end{array}$ & $.26^{*}$ & $.13^{*}$ & .07 & $.27 *$ & $.26^{*}$ \\
\hline 14.Yüksek standartlar & .07 & $.12 *$ & .03 & $.12 *$ & $.14^{*}$ \\
\hline
\end{tabular}

Tablo 3’te görüldüğü gibi, büyüme korkusunun sosyal duygusal yalnızlık alt boyutu ile duygusal yoksunluk $(\mathrm{r}=.34, \mathrm{p}<.05)$, başarısızlık $(\mathrm{r}=.25, \mathrm{p}<.05)$, karamsarlık $(\mathrm{r}=.28, \mathrm{p}<.05)$, sosyal izolasyon/güvensizlik $(\mathrm{r}=.45, \mathrm{p}<.05)$, duyguları bastırma $(\mathrm{r}=.16, \mathrm{p}<.05)$, iç içe geçme/bağımlılık ( $\mathrm{r}=.22, \mathrm{p}<.05)$, ayrıcalıklılık/yetersiz öz denetim $(\mathrm{r}=.10, \mathrm{p}<.05)$, terkedilme $(\mathrm{r}=.18, \mathrm{p}<.05)$, kusurluluk $(\mathrm{r}=.31, \mathrm{p}<.05)$ ve tehditler karşısında dayanıksızlık $(\mathrm{r}=.26, \mathrm{p}<.05)$ şemaları arasında pozitif yönde anlamlı ilişkiler bulunmaktadır.

Büyüme korkusunun romantik ilişkiyi sürdürmede zorlanma alt boyutu ile duygusal yoksunluk $(\mathrm{r}=.19, \mathrm{p}<.05)$, başarısızlık $(\mathrm{r}=.13, \mathrm{p}<.05)$, karamsarlık $(\mathrm{r}=.13, \mathrm{p}<.05)$, sosyal izolasyon/güvensizlik $(\mathrm{r}=.18, \mathrm{p}<.05)$, duyguları bastırma $(\mathrm{r}=.20, \mathrm{p}<.05)$, iç içe geçme/bağımlılık $(\mathrm{r}=.15, \mathrm{p}<.05)$, ayrıcalıklılık/yetersiz öz denetim $(\mathrm{r}=.25, \mathrm{p}<.05)$, kusurluluk $(\mathrm{r}=.29, \mathrm{p}<.05)$, tehditler karşısında dayanıksızlık $(\mathrm{r}=.13, \mathrm{p}<.05)$ ve yüksek standartlar $(\mathrm{r}=.12, \mathrm{p}<.05)$ şemaları arasında pozitif yönde anlamlı ilişkiler bulunmaktadır.

Büyüme korkusunun evliliğe karşı olumsuz tutum alt boyutu ile başarısızlık ( $\mathrm{r}=.13$, $\mathrm{p}<.05)$, karamsarl1k $(\mathrm{r}=.10, \mathrm{p}<.05)$, sosyal izolasyon/güvensizlik $(\mathrm{r}=.17, \mathrm{p}<.05)$, duygular1 bastırma $(\mathrm{r}=.11, \mathrm{p}<.05)$, iç içe geçme/bağımlılık $(\mathrm{r}=.18, \mathrm{p}<.05)$, ayrıcalıklılık/yetersiz öz denetim $(\mathrm{r}=.26, \mathrm{p}<.05)$, kusurluluk $(\mathrm{r}=.20, \mathrm{p}<.05)$ şemalari arasında pozitif yönde anlamlı ilişkiler bulunmaktadır. 
Büyüme korkusunun bağımsız yaşama hazırlık ve sorumluluğu içselleştirmede zorlanma alt boyutu ile duygusal yoksunluk $(\mathrm{r}=.14, \mathrm{p}<.05)$, başarısızlık $(\mathrm{r}=.25, \mathrm{p}<.05)$, karamsarlık $(\mathrm{r}=.22, \mathrm{p}<.05)$, sosyal izolasyon/güvensizlik $(\mathrm{r}=.20, \mathrm{p}<.05)$, duyguları bastırma $(\mathrm{r}=.15, \mathrm{p}<.05)$, onay arayıcılık $(\mathrm{r}=.16, \mathrm{p}<.05)$, iç içe geçme/bağımlılık $(\mathrm{r}=.24, \mathrm{p}<.05)$, ayrıcalıkl11ık/yetersiz öz denetim $(\mathrm{r}=.37, \mathrm{p}<.05)$, terkedilme $(\mathrm{r}=.14, \mathrm{p}<.05)$, kusurluluk $(\mathrm{r}=.28$, $\mathrm{p}<.05)$ ve tehditler karşısında dayanıksızlık $(\mathrm{r}=.27, \mathrm{p}<.05)$, yüksek standartlar $(\mathrm{r}=.12, \mathrm{p}<.05)$ şemalari arasında pozitif yönde anlamlı ilişkiler bulunmaktadır.

Büyüme korkusu toplam puanı ile duygusal yoksunluk ( $\mathrm{r}=.29, \mathrm{p}<.05)$, başarısızlık $(\mathrm{r}=.27, \mathrm{p}<.05)$, karamsarlık $(\mathrm{r}=.26, \mathrm{p}<.05)$, sosyal izolasyon/güvensizlik $(\mathrm{r}=.36, \mathrm{p}<.05)$, duyguları bastırma $(\mathrm{r}=.24, \mathrm{p}<.05)$, iç içe geçme/bağımlılık $(\mathrm{r}=.29, \mathrm{p}<.05)$, ayrıcalıklılık/yetersiz özdenetim $(\mathrm{r}=.38, \mathrm{p}<.05)$, terkedilme $(\mathrm{r}=.15, \mathrm{p}<.05)$, kusurluluk $(\mathrm{r}=.41, \mathrm{p}<.05)$, tehditler karşısında dayanıksızlık $(\mathrm{r}=.26, \mathrm{p}<.05)$ ve yüksek standartlar $(\mathrm{r}=.14, \mathrm{p}<.05)$ şemaları arasında pozitif yönde anlamlı ilişki bulunmaktadır.

Büyüme korkusu ile anne ve babaya ilişkin algılanan ebeveynlik biçimleri arasındaki ilişkiye ait Pearson Korelasyon Analizi sonuçları Tablo 4'te görülmektedir.

Tablo 4. Büyüme korkusu ile anne ve babaya ilişkin algılanan ebeveynlik biçimleri arasındaki ilişkiye dair pearson korelasyon analizi sonuçları $(\mathrm{N}=400)$

\begin{tabular}{|c|c|c|c|c|c|}
\hline $\begin{array}{l}\text { Anneye İlişkin Algılanan } \\
\text { Ebeveynlik }\end{array}$ & $\begin{array}{c}\text { Büyüme } \\
\text { Korkusu } \\
\text { Sosyal } \\
\text { Duygusal } \\
\text { Yalnızlık } \\
\text { Alt Boyutu }\end{array}$ & $\begin{array}{c}\text { Büyüme } \\
\text { Korkusu } \\
\text { Romantik } \\
\text { İlişkiyi } \\
\text { Sürdürmede } \\
\text { Zorlanma } \\
\text { Alt Boyutu }\end{array}$ & $\begin{array}{c}\text { Büyüme } \\
\text { Korkusu } \\
\text { Evliliğe } \\
\text { Karş1 } \\
\text { Olumsuz } \\
\text { Tutum Alt } \\
\text { Boyutu }\end{array}$ & $\begin{array}{c}\text { Büyüme } \\
\text { Korkusu } \\
\text { Bağımsız } \\
\text { Yaşama } \\
\text { Hazırlık ve } \\
\text { Sorumluluğu } \\
\text { İçselleştirmede } \\
\text { Zorlanma Alt } \\
\text { Boyutu }\end{array}$ & $\begin{array}{c}\text { Büyüme } \\
\text { Korkusu } \\
\text { Toplam } \\
\text { Puan }\end{array}$ \\
\hline $\begin{array}{l}\text { 1.Değişime kapal1/duyguları } \\
\text { bastıran (anne) }\end{array}$ & .06 & .02 & .03 & $.14 *$ & .07 \\
\hline 2.Cezalandirıcı (anne) & $.13^{*}$ & $.16^{*}$ & .03 & $.17 *$ & $.19^{*}$ \\
\hline 3.Kötümser/endişeli (anne) & $.11^{*}$ & .06 & .01 & .06 & .08 \\
\hline $\begin{array}{l}\text { 4.Aşırı izin verici/sınırsız } \\
\text { (anne) }\end{array}$ & .02 & .04 & .06 & $.13 *$ & .09 \\
\hline $\begin{array}{l}\text { 5.Koşullu/başarı odaklı } \\
\text { (anne) }\end{array}$ & .01 & .06 & .00 & $.19 *$ & .09 \\
\hline $\begin{array}{l}\text { 6.Aşırı koruyucu/evhamlı } \\
\text { (anne) }\end{array}$ & $.18^{*}$ & .07 & .06 & $.14 *$ & $.17 *$ \\
\hline $\begin{array}{l}\text { 7.Sömürücü/istismar edici } \\
\text { (anne) }\end{array}$ & .06 & .00 & .00 & .05 & .03 \\
\hline $\begin{array}{l}\text { 8.Duygusal bakımdan } \\
\text { yoksun bırakıc1 (anne) }\end{array}$ & $.15^{*}$ & $.12 *$ & .02 & .08 & $.15^{*}$ \\
\hline $\begin{array}{l}\text { 9.Küçümseyici/kusur } \\
\text { bulucu (anne) }\end{array}$ & $.16^{*}$ & $.11^{*}$ & .09 & $.15^{*}$ & $.19 *$ \\
\hline $\begin{array}{l}\text { 10.Kuralc1/kalıplayıcı } \\
\text { (anne) } \\
\text { Babaya İlişkin Algılanan } \\
\text { Ebeveynlik }\end{array}$ & .09 & .07 & .06 & $.20 *$ & $.16^{*}$ \\
\hline $\begin{array}{l}\text { 1.Değişime kapalı/duyguları } \\
\text { bastıran (baba) }\end{array}$ & $.11 *$ & .04 & .00 & $.10^{*}$ & .09 \\
\hline 2.Cezalandırıcı (baba) & $.22 *$ & .09 & .02 & $.10^{*}$ & $.16^{*}$ \\
\hline 3.Kötümser/endişeli (baba) & $.18^{*}$ & .05 & .07 & .07 & $.14^{*}$ \\
\hline $\begin{array}{l}\text { 4.Aşırı izin verici/sınırsız } \\
\text { (baba) }\end{array}$ & .07 & .06 & .06 & $.12 *$ & $.12 *$ \\
\hline $\begin{array}{l}\text { 5.Koşullu/başarı odaklı } \\
\text { (baba) }\end{array}$ & .03 & .01 & .02 & .08 & .01 \\
\hline 6.Aşırı koruyucu/evhamlı & $.20 *$ & .01 & .07 & .09 & $.13 *$ \\
\hline
\end{tabular}


(baba)

7.Sömürücü/istismar edici

(baba)

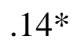

8.Duygusal bakımdan

yoksun birakıcı (baba)

9.Küçümseyici/kusur

bulucu (baba)

10.Kuralc1/kalıplayıc

(baba)

$\begin{array}{lllll}.14 * & 04 . & .02 & .03 & .07 \\ .20 * & .07 & .02 & .01 & .09 \\ .25 * & .06 & .01 & .09 & .15^{*} \\ .04 & .02 & .02 & .08 & .06\end{array}$

Tablo 4'te görüldüğü gibi, büyüme korkusunun alt boyutu olan sosyal duygusal yalnızlık ile cezalandırıcı $(\mathrm{r}=.13, \mathrm{p}<.05), \quad$ kötümser/endişeli $(\mathrm{r}=.11, \quad \mathrm{p}<.05), \quad$ aşırı koruyucu/evhamlı ( $\mathrm{r}=.18, \mathrm{p}<.05)$, duygusal bakımdan yoksun birakıc1 $(\mathrm{r}=.15, \mathrm{p}<.05)$, küçümseyici/kusur bulucu ( $\mathrm{r}=.16, \mathrm{p}<.05)$ olarak algılanan anne arasında pozitif yönde anlamlı ilişkiler bulunmuştur. Ayrıca büyüme korkusunun alt boyutu olan sosyal duygusal yalnızlık ile değişime kapalı duyguları bastıran $(\mathrm{r}=.11, \mathrm{p}<.05)$, cezalandırıcı $(\mathrm{r}=.22, \mathrm{p}<.05)$, kötümser/endişeli $(r=.18, p<.05)$, aşır1 koruyucu/evhamlı $(r=.20, p<.05)$, sömürücü/istismar edici $(r=.14, p<.05)$, duygusal bakımdan yoksun bırakıcı $(r=.20, p<.05)$, küçümseyici/kusur bulucu $(\mathrm{r}=.25, \mathrm{p}<.05)$ olarak algılanan baba arasında pozitif yönde anlamlı ilişkiler ortaya konmuştur.

Büyüme korkusunun alt boyutu olan romantik ilişkiyi sürdürmede zorlanma ile cezalandırıc1 $(\mathrm{r}=.16, \mathrm{p}<.05)$, duygusal bakımdan yoksun birakıc1 $(\mathrm{r}=.12, \mathrm{p}<.05)$, küçümseyici/kusur bulucu $(\mathrm{r}=.11, \mathrm{p}<.05)$ olarak algılanan anne arasında pozitif yönde anlamlı ilişkiler bulunmuştur. Büyüme korkusunun alt boyutu olan romantik ilişkiyi sürdürmede zorlanma ile babaya ilişkin algılanan ebeveynlik tutumları arasında anlamlı ilişkiler bulunamamıştır.

Büyüme korkusunun alt boyutlarından olan evliliğe karşı olumsuz tutum ile anne ve babaya ilişkin algılanan ebeveynlik tutumları arasında anlamlı ilişkiler bulunamamıştır.

Büyüme korkusunun bağımsız yaşama hazırlık ve sorumluluğu içselleştirmede zorlanma alt boyutu ile değișime kapalı/duyguları bastıran $(r=.14, p<.05)$, cezalandırıcı $(r=.17$, $\mathrm{p}<.05)$, aşırı izin verici/sınırsız $(\mathrm{r}=.13, \mathrm{p}<.05)$, koşullu başarı odaklı $(\mathrm{r}=.19, \mathrm{p}<.05)$, aşırı koruyucu/evhamlı ( $\mathrm{r}=.14, \mathrm{p}<.05)$, küçümseyici/kusur bulucu $(\mathrm{r}=.15, \mathrm{p}<.05)$, kuralcı/kalıplayıcı $(\mathrm{r}=.20, \mathrm{p}<.05)$ olarak algılanan anneye ilişkin ebeveynlik biçimleri arasında pozitif yönde anlamlı ilişkiler bulunmuştur. Büyüme korkusunun bağımsız yaşama hazırlık alt boyutu ile değişime kapalı/duyguları bastıran $(\mathrm{r}=.10, \mathrm{p}<.05)$, cezalandırıcı $(\mathrm{r}=.10, \mathrm{p}<.05)$, aşırı izin verici/sınırsız $(\mathrm{r}=.12, \mathrm{p}<.05)$ olarak algılanan babaya ilişkin ebevenlik biçimleri arasında pozitif yönde anlamlı ilişkiler bulunmuştur.

Büyüme korkusu toplam puanı ile cezalandırıcı $(\mathrm{r}=.19, \mathrm{p}<.05)$, aşırı koruyucu/evhamlı $(\mathrm{r}=.17, \mathrm{p}<.05)$, duygusal bakımdan yoksun bırakıcı $(\mathrm{r}=.15, \mathrm{p}<.05)$, küçümseyici/kusur bulucu $(\mathrm{r}=.19, \mathrm{p}<.05)$, ve kuralc1/kalıplayıcı $(\mathrm{r}=.16, \mathrm{p}<.05)$ olarak algılanan anneye ilişkin ebeveynlik biçimleri arasında pozitif yönde anlamlı ilişkiler bulunmuştur. Ayrıca, büyüme korkusu toplam puanı ile cezalandırıcı $(\mathrm{r}=.16, \mathrm{p}<.05)$, kötümser/endişeli $(\mathrm{r}=.14, \mathrm{p}<.05)$, aşırı izin verici/sınırsız $(\mathrm{r}=.12, \mathrm{p}<.05)$, aşırı koruyucu/evhamlı $(\mathrm{r}=.13, \mathrm{p}<.05)$, küçümseyici/kusur bulucu $(\mathrm{r}=.15, \mathrm{p}<.05)$ olarak algılanan babaya ilişkin ebeveynlik biçimleri arasında ise pozitif yönde anlamlı ilişkiler vardir.

Örneklem grubunun büyüme korkusu düzeylerinin demografik özelliklere göre farklılaşıp farklılaşmadığını saptamak için yapılan Bağımsız Örneklemli t-Testi sonuçlarına göre gruplar arasında anlamlı farklılık bulunmamıştır.

\section{Tartışma}

Çalışmada büyüme korkusu ile erken dönem uyumsuz şemalar ve algılanan ebeveyn biçimleri arasındaki ilişkiler incelenmiştir. Bu amaç doğrultusunda 400 kişilik örneklem grubu 
ile yapılan çalışma sonuçları genel olarak değerlendirildiğinde, büyüme korkusu toplam puanı ile duygusal yoksunluk, başarısızlık, karamsarlık, sosyal izolasyon/güvensizlik, duyguları bastırma, iç içe geçme/bağımlılık, ayrıcalıklılık/yetersiz özdenetim, terkedilme, kusurluluk, tehditler karşısında dayanıksızlık ve yüksek standartlar şemaları arasında pozitif yönde anlamlı ilişkiler saptanmıştır. Anı, duygu, biliş ve bedensel duyumlardan oluşan erken dönem uyumsuz şemalar, kişilerin kendine ve diğerleriyle olan ilişkilerine dair algılarını içermektedir (Young, Klosko ve Weishaar, 2003). Sevgisiz, desteksiz ve ilgisiz bir aile ortamında yetişen bireylerde olumsuz erken dönem uyum bozucu şemaların gelişme oranı daha yüksektir (Kapçı ve Hamamc1, 2010). Kiley (1983) "Peter Pan Sendromu, Hiç Büyümeyen Erkekler" adlı kitabında büyümekten korkan kişilerin ailelerinde çoğunlukla iletişim problemi olduğunu ve bu yüzden bukişilerin tedirginlik yaşadıklarını belirtmiştir.

$\mathrm{Bu}$ çalışmada sosyal duygusal yalnızlık yaşayan insanların diğer kişilere mesafeli oluşu, yakınlık kurmada zorlanmaları gibi özellikleri göz önünde bulundurularak büyüme korkusunun alt boyutlarından olan sosyal duygusal yalnızlı ile duygusal yoksunluk, terkedilme, duyguları bastırma ve sosyal izolasyon/güvensizlik şemalarının birbirleri ile anlamlı bir şekilde ilişkili olacağı varsayımında bulunulmuştur. $\mathrm{Bu}$ araştırmanın sonucuna göre ise, bu varsayım doğrulanmış, varsayımda bulunulan bu şemalar dışında ayrıca büyüme korkusunun sosyal duygusal yalnızlık alt boyutunun, başarısızlık, karamsarlık, iç içe geçme/bağımlılık, ayrıcalıklılık/yetersiz öz denetim, kusurluluk ve tehditler karşısında dayanıksızlık şemaları ile de ilişkili olduğu bulunmuştur. Bu sonuçlar değerlendirildiğinde, sosyal duygusal yalnızlık yaşayan bir bireyin, başarısızlık ve karamsarlık şemaları ile bağlantılı olarak özellikle sosyal ilişkilerinde başarısızlık ve karamsarlık hissedebilecekleri düşünülmektedir. Yetersiz öz denetim, tehlikelere karşı dayanıksızlık ve bağımlılık şemaları ile bağlantılı olarak, ilişkilerde yaşanabilecek olumsuzluklara karşı hasasiyet gösterme ve diğer kişilerle ilişki kurarak belli işleri tamamlama süreçlerinde zorlandıklarından yakın çevreden bir ya da iki kişiye karşı kendini bağımlı hissetme süreçlerini yaşayabilecekleri düşünülmektir. Dolayısıyla tüm bu sonuçların sosyal duygusal yalnızlık yaşayan bir bireyin göstermesi beklenen davranış özellikleri ve şemalar ile tutarlı ve uyumlu olduğu düşünülmektedir.

Büyüme korkusunun romantik ilişkiyi sürdürmede zorlanma alt boyutu ile duygusal yoksunluk, başarısızlık, karamsarlık, sosyal izolasyon/güvensizlik, duyguları bastırma, iç içe geçme/bağımlılık, ayrıcalıklılık/yetersiz öz denetim, kusurluluk, tehditler karşısında dayanıksılık ve yüksek standartlar şemaları arasında pozitif yönde anlamlı ilişkiler bulunmuştur. $\mathrm{Bu}$ çalışmada, büyüme korkusunun romantik ilişkiyi sürdürmede zorlanma alt boyutu ile ilişkili bulunan şemalardan yüksek standartlar şeması dışındaki diğer tüm şemalarla ilişkili olabileceği varsayımı bu çalışmanın araştırmacıları tarafından yapılmıştır. Araştırmacıların varsayımının dışında kalan yüksek standartlar şemasının romantik ilişkiyi sürdürmede zorlanma ile ilişkili bulunmasının olası nedenleri ile ilgili olarak, yüksek standartlara sahip kişilerin romantik partnerinin ilişki içerisindeki davranışlarının ve ilişki içerisinde yaşanan tüm anların yüksek standartlar çerçevesinde gerçekleşmesi beklentisi içerisinde olduklarından romantik ilişkileri sürdürmede zorlanabilecekleri düşünülmüştür. Kiley (1983) bu görüşü destekler nitelikte, "Peter Pan sendromu" kapsamında, büyüme korkusu yaşayan kişilerin romantik partnerinin belirli bir modelde davranmasını istediklerini ve romantik partnerleri kendilerinin zihinlerindeki kalıplardan, beklentilerinden uzaklaşırsa aşırı rahatsız olabileceklerini belirtmektedir.

Büyüme korkusunun evliliğe karşı olumsuz tutum alt boyutu ile başarısızlık karamsarlık, sosyal izolasyon/güvensizlik, duyguları bastırma, iç içe geçme/bağımlılık, ayrıcalıklılık/yetersiz öz denetim, kusurluluk şemalari arasında pozitif yönde anlamlı ilişkiler bulunmuştur. Elde edilen bu bulgular, bu çalışmada bu alt boyutun hangi şemalarla ilişkili olabileceği doğrultusunda bu çalışmanın araştırmacıları tarafından yapılan varsayımla tutarlıdır.

Büyüme korkusu kavramı "bağımsız yaşama hazırlık ve sorumluluğu içselleştirmede zorlanma" alt boyutunu da içermektedir (Ateş ve Özden Yıldırım, 2018). Bu doğrultuda, 
büyüme korkusu düzeyi yüksek olan kişilerin sorumluluklarını içselleştirmede zorlanmaları sebebiyle, sorumluluklarını yerine getirmediklerinde kendilerine karşı pek cezalandırıcı olmayacakları, ötekilere karşı fedakâr davranarak aşırı sorumluluk almayacakları düşünülmektedir. $\mathrm{Bu}$ sebeple bu çalışmada büyüme korkusu yapısının genel olarak cezalandırıcılık ve kendini feda şemaları ile anlamlı ilişki göstermeyeceği varsayımı yapılmıştır. $\mathrm{Bu}$ çalışmanın sonucuna göre ise bu varsayım doğrulanmış, büyüme korkusunun hiçbir alt boyutu ve toplam puanı ile cezalandırıcılık ve kendini feda şemaları arasında anlamlı ilişkiler bulunamadığı dikkati çekmiştir. Kiley'e (1983) göre, "Peter Pan sendromu" kapsamında büyüme korkusu yaşayan kişiler ailelerinden gelen sorumsuzluğa dair öğretiler ve ailelerinin gergin ortamından gelen tedirginlik ile bağlantılı olarak, üşengeç davranabilmektedirler. Harcadıkları enerjinin sadece daha fazla başarısızlıkla sonuçlanacağını düşünerek kaderci bir üşengeçlik içerisinde bulunurlar (Kiley, 1983). Bu doğrultuda, bu çalışmanın sonucuna göre büyüme korkusunun tüm alt boyutları ile ayrıcalıklılık/yetersiz özdenetim şeması arasında orta düzeyde ve pozitif yönde anlamlı ilişki bulunmasının, büyüme korkusu yüksek olan kişilerin sorumluluk ve öz denetim gerektiren durumlardan kaçındıkları yorumu ile tutarlılık gösterdiği söylenebilir.

Algılanan ebeveynlik biçimleri ile büyüme korkusu toplam puanı arasındaki ilişkilerin test edilmesi sonucunda büyüme korkusu ile cezalandırıcı, kötümser/endişeli, aşırı izin verici/sınırsız, aşırı koruyucu/evhamlı, küçümseyici/kusur bulucu olarak algılanan babaya ilişkin ebeveynlik biçimleri arasında pozitif yönde anlamlı ilişkiler saptanmıştır. Büyüme korkusu toplam puanı ile cezalandırıcı, aşırı koruyucu/evhamlı, duygusal bakımdan yoksun bırakıcı, küçümseyici/kusur bulucu ve kuralcı/kalıplayıcı olarak algılanan anneye ilişkin ebeveynlik biçimleri arasında da pozitif yönde anlamlı ilişki bulunmuştur. Çalışmanın bulgularıyla paralel olarak alanyazında yapılmış çalışmalar da kişilerin erken dönem yaşantılarında ebeveynleriyle kurdukları ilişkilerin yaşamlarının ileri dönemlerinde kişilerarası ilişkilerini, diğer kişilere ve dünyaya yönelik algı, duygu, düşünce ve şemalarını etkilediğini göstermektedir (Ainsworth ve Bowlby, 1991; Beck ve Emery, 2006; Young, Klosko ve Weishaar, 2003). Kapçı ve Hamamcı (2010) tarafından yapılan çalışmada da işlevsel olmayan ailelerde yetişen kişiler, sosyal bir gruba ait olamayacağ (sosyal yalıtılmışlık şeması), duygusal iliş̧ki gereksinimlerinin yeterince karşılanamayacağ 1 (duygusal yoksunluk şeması), duygularını göz ardı etmesi gerektiği (duyguları bastırma şeması) ve diğerlerinin onu inciteceği (güvensizlik şeması) inancı geliştirebilecekleri ifade edilmiştir.

Büyüme korkusunun alt boyutu olan sosyal duygusal yalnızlık ile cezalandırıc1, kötümser/endişeli, aşırı koruyucu/evhaml, duygusal bakımdan yoksun bırakıc1, küçümseyici/kusur bulucu olarak algılanan anne arasında pozitif yönde anlamlı ilişkiler bulunmuştur. Ayrıca büyüme korkusunun alt boyutu olan sosyal duygusal yalnızlık ile değişime kapalı duyguları bastıran, cezalandırıcı, kötümser/endişeli, aşırı koruyucu/evhamlı, sömürücü/istismar edici, duygusal bakımdan yoksun bırakıcı, küçümseyici/kusur bulucu algılanan baba arasında pozitif yönde anlamlı ilişkiler ortaya konmuştur. Sosyal duygusal yalnızlık yaşayan kişiler tarafından anne ve babanın hem duygusal bakımdan yoksun bırakıcı hem de aşırı koruyucu/evhamlı olarak algılanmalarının zıtlık içeren, çelişkili bir sonuç olduğu dikkati çekmektedir. Benzer şekilde babanın hem aşırı koruyucu/evhamlı hem de sömürücü/istismar edici olarak algılanması da babanın kendi içerisinde çelişkili tutumlara sahip olabileceğini düşündürtmektedir. Bu çelişkili sonuçların büyüme korkusu kapsamında sosyal duygusal yalnızlık yaşayan kişilerin annelerinin ve babalarının ebeveynlik davranışlarında tutarsız olduklarına dair bir işaret olarak yorumlanabileceği düşünülmektedir. Ayrıca bu alt boyut özelinde, anneden farklı olarak babanın sömürücü/istismar edici ve değişime kapalı/duyguları bastıran bir tutum içerisinde de olabildiği görülmektedir. Anne ve babada ortak olarak algılanan ebeveynlik biçimlerinden bir diğeri ise küçümseyici/kusur bulucu ebeveynlik biçimidir. Bu sonuç bu çalışmada elde edilen bir diğer bulgu olan sosyal duygusal yalnızlık yaşayan kişilerin kusurluluk şemasına sahip olmaları ile tutarlılık göstermektedir. Ayrıca bu sonuç anne ve babası küçümseyici/kusur bulucu olan kişilerin kusurluluk şemasına sahip 
oldukları ve sosyal duygusal yalnızlık yaşadıklarına işaret etmektedir.

Büyüme korkusunun alt boyutu olan romantik ilişkiyi sürdürmede zorlanma ile cezalandırıcı, duygusal bakımdan yoksun bırakıcı, küçümseyici/kusur bulucu olarak algılanan anne arasında pozitif yönde anlamlı ilişkiler bulunmuştur. Büyüme korkusunun alt boyutu olan romantik ilişkiyi sürdürmede zorlanma ile babaya ilişkin algılanan ebeveynlik tutumları arasında anlamlı ilişkiler bulunamamıştır. Bu doğrultuda büyüme korkusu ile ilgili olarak romantik ilişkileri sürdürmede zorlanmanın babanın ebeveynlik biçiminden ziyade daha çok annenin olumsuz ebeveynlik biçimi ile ilişkili olabileceği yorumu yapılabilir.

Büyüme korkusunun alt boyutlarından olan evliliğe karşı olumsuz tutum ile anne ve babaya ilişkin algılanan ebeveynlik tutumları arasında anlamlı ilişkiler bulunamamıştır. $\mathrm{Bu}$ sonuç büyüme korkusu ile ilgili olarak evliliğe yönelik olumsuz tutumun ebeveynlik biçimi yerine başka bir değişkenle ilişkili olabileceğini düşündürtmektedir.

Büyüme korkusunun bağımsız yaşama hazırlık ve sorumluluğu içselleştirmede zorlanma alt boyutu ile değişime kapalı/duyguları bastıran, cezalandırıcı, aşırı izin verici/sınırsız, koşullu başarı odaklı, aşırı koruyucu/evhamlı, küçümseyici/kusur bulucu, kuralcı/kalıplayıcı olarak algılanan anneye ilişkin ebeveynlik biçimleri arasında pozitif yönde anlamlı ilişkiler bulunmuştur. Ayrıca bu alt boyut ile değişime kapalı/duyguları bastıran, cezalandırıcı, aşırı izin verici/sınırsız olarak algılanan babaya ilişkin ebevenlik biçimleri arasında pozitif yönde anlamlı ilişkiler bulunmuştur. $\mathrm{Bu}$ alt boyut özelinde annenin hem cezalandırıcı hem de aşırı izin verici/sınırsız olarak algılanmasının zıtlık içeren, çelişkili bir sonuç olduğu dikkati çekmektedir. Bu sonucun, büyüme korkusu kapsamında bağımsız yaşama hazırlık ve sorumluluğu içselleştirmede zorlanma yaşayan kişilerin annelerinin ebeveynlik davranışlarında tutarsız olduklarına dair bir işaret olarak yorumlanabileceği düşünülmektedir. Baba ile ilgili algılanan ebeveynlik ile büyüme korkusu arasındaki ilişkilere dair sonuçlar incelendiğinde, büyüme korkusunun alt boyutu olan bağımsız yaşama hazırlık ve sorumluluğu içselleştirmede zorlanma ile kuralcı kalıplayıcı ve koşullu başarı odaklı ebeveynlik gibi çocukta olumsuz yönde aşırı sorumluluk duygularına yol açabilecek ebeveynlik biçimleri arasında anlamlı ilişkiler bulunmadığı dikkati çekmektedir. Büyüme korkusu kapsamında bağımsız yaşama hazırlık ve sorumluluğu içselleştirmede zorlanma düzeyi yüksek kişilerde aşırı sorumluluğun tam tersi olarak, sorumluluğu içselleştirmede zorlanmanın yaşanmasının kuralcı kalıplayıcı ve koşullu başarı odaklı ebeveynlik göstermeyen, aşırı izin verici ebeveynlik gösteren bir babanın varlığı ile uyumlu ve tutarlı olduğu düşünülmektedir. Ayrıca bu kişilerin babalarını hem aşırı izin verici hem de cezalandırıcı olarak algılamalarına dair sonuçların ise babaların ebeveynlik davranışlarında genel olarak tutarsız olabildiklerine dair bir işaret olarak yorumlanabileceği düşünülmektedir.

\section{Sonuç ve Öneriler}

Özetle, genel olarak anne ve baba tarafından algılanan ebeveynliğin büyüme korkusunu etkilediği ve kendini feda ve cezalandırıcılık şemaları dışında erken dönem uyumsuz şemalarla büyüme korkusunun ilişkili oldukları sonucuna ulaşılmıştır.

Büyüme korkusu demografik değişkenler açısından ele alındığında gruplar arasında cinsiyet, gelir düzeyi, eğitim düzeyi, çalışıp çalışmama bakımından farklılık bulunmamıştır. Burada çalışmaya katılan kişilerin sadece İstanbul ilinde yaşayan kişiler olmaları da çalışma açısından bir sınırlılık oluşturmaktadır. Sosyokültürel faktörler açısından çeşitlilik sağlanabilecek bir örneklem grubuyla çalışıldığında farklı sonuçlar elde edilebileceği düşünülmektedir. Ayrıca çalışmaya katılan katılımcılar çoğunlukla orta sosyoekonomik düzeyde yoğunluk kazanmıştır. Çalışma, farklı sosyoekonomik seviyelerdeki katılımcı sayıları arttırılarak tekrarlanırsa demografik özellikler açısından da çalışma bulgularında farklı sonuçlar elde edilebilir. Değinilen sınırlılıklarıyla beraber, çalışmadan elde edilen bulgular yeni bir yapı olarak "büyüme korkusu" nun algılanan ebeveynlik biçimleri ve şemalar ile ilişkisi doğrultusunda daha detaylı incelenmesini sağlamıştır. Gelecek çalışmalarda büyüme korkusu ile 
erken dönemde kurulan bağlanma arasındaki ilişkiler de incelenebilir. Buna ek olarak ebeveynlerin boşanmış olup olmamaları da hem büyüme korkusu ile hem de erken dönem uyumsuz şemalar ile ele alınabilir. Ayrıca büyüme korkusu, algılanan ebeveynlik, erken dönem uyumsuz şemalar ve psikolojik belirtilerin içerisinde bulunduğu bir araştırma modelinin test edilmesi ile bu kavramların nedensellik ve birbirinin öncülü veya sonucu olma açısından incelenmesinin alan yazına katkı sağlayacağı düşünülmektedir. Buna ek olarak, test edilecek bu modelin büyüme korkusu ve psikolojik belirtilerin önlenmesi doğrultusunda çalışma gösteren klinisyenlere psikoterapi sürecinde müdahale planı oluşturma açısından katkı sağlayacağı düşünülmektedir.

\section{Kaynakça}

Ainsworth, M.S. ve Bowlby, J. (1991). An ethological approach to personality development. American Psychologist, 46(4), 333-341.

Arnett, J.J. (2000). Emerging adulthood: a theory of development from the late teens through the twenties. American Psychologist, 55(5), 469-480.

Atak, H. ve Çok, F. (2010). Beliren yetişkinlik (emerging adulthood): insan yaşamında yeni bir dönem. Çocuk ve Gençlik Ruh Sağlığı Dergisi, 17(1), 39-50.

Ateş, N. ve Özden Yıldırım, M.S. (2018). Büyüme Korkusu Ölçeği'nin (BKÖ) geliştirilmesi: geçerlilik ve güvenirlik çalışması. Mehmet Akif Ersoy Üniversitesi Sosyal Bilimler Enstitüsü Dergisi, 10(24), 158-175. Doi: 10.20875/makusobed.380022.

Başbuğ, S., Cesur, G. ve Batıün, A. D. (2017). Algılanan ebeveynlik biçimi ve yetişkin ayrılma anksiyetesi: kişilerarası bilişsel çarpıtmaların aracı rolü. Türk Psikiyatri Dergisi, 28, 255267.

Beck, A. ve Emery, G. (2006). Anksiyete bozuklukları ve fobiler. (V. Öztürk Çev.). İstanbul: Litera Yayınc1lı.

Bowlby, J. (1973). Attachment and loss: Vol. 2. Separation: Anxiety and anger. New York: Basic Books.

Doğan, A. ve Cebioğlu, S. (2011). Beliren yetişkinlik: Ergenlikten yetişkinliğe uzanan bir dönem. Türk Psikoloji Yazllarl, 14(28), 11-21.

Harris, A. ve Curtin, L. (2002). Parental perceptions, early maladaptive schemas, and depressive symptoms in young adults. Cognitive Therapy Research, 26(3), 405-416.

Hoffart, A. (2012). The case formulation process in schema therapy of chronic axis I disorder (Affective/Anxiety Disorders). M. van Vreeswijk, J. Broersen ve M. Nadort (Ed.), The Wiley - Blackwell Handbook of Schema Therapy: Theory, Research and Practice içinde (69-80). United Kingdom: Wiley-Blackwell.

Kapçı, E.G. ve Hamamcı, Z. (2010). Aile işlevi ile psikolojik belirtiler arasındaki ilişki: erken dönem uyum bozucu şemaların aracı rolü, Klinik Psikiyatri, 13, 127-136.

Karasar, N. (2016). Bilimsel araştırma yöntemi. (30. basım) Ankara: Nobel.

Kiley, D. (1983). The Peter Pan syndrome: Men who have never grown up. New York: Dodd Mead.

Özden, M.S. (2013). Önceden edinilmiş ve sonradan kazanılmış gelişim özelliklerinin evlilikte çift uyumu ile ilişkisi (Doktora tezi). İstanbul: Maltepe Üniversitesi Sosyal Bilimler Enstitüsü.

Sable, P. (2008). What is adult attachment?. Clinical Social Work Journal, 36(1), 21-30. 
Sheffield, A., Waller, G., Emanuelli, F. ve Murray, J. (2006). Is comorbidity in the eating disorders related to perceptions of parenting? criterion validity of the revised young parenting inventory. Eating Behaviors, 7(1), 37-45.

Soygüt, G., Çakır, Z. ve Karaosmanoğlu, A. (2008). Ebeveynlik biçimlerinin değerlendirilmesi: young ebeveynlik ölçeği'nin psikometrik özelliklerine ilişkin bir inceleme. Türk Psikoloji Yazlları, 11(22), 17-30.

Soygüt, G. ve Çakır, Z. (2009). Ebeveynlik biçimleri ile psikolojik belirtiler arasındaki ilişkilerde kişilerarası şemaların aracı rolü: şema odaklı bir bakış. Türk Psikiyatri Dergisi, 20(2), 144-152.

Soygüt, G., Karaosmanoğlu, A. ve Çakır, Z. (2009). Assessment of early maladaptive schemas: a psychometric study of the Turkish Young Schema Questionnaire-Short Form 3. Turkish Journal of Psychiatry, 20(1), 75-84.

Yavuzer, H. (2011). Ana-baba ve çocuk (22. Basım). İstanbul: Remzi Kitabevi.

Young, J. E. (1999). Practitioner's resource series. Cognitive therapy for personality disorders: A schema-focused approach. Professional Resource Press/Professional Resource Exchange.

Young, J. (1994). Young ebeveynlik ölçeği. Basılmamış Rapor.

Young, J. E. ve Klosko, J. S. (2011). Hayatı yeniden keşfedin. (S. Kohen ve D. Güler, Çev.). (1993), İstanbul: Psikonet Yayınları.

Young, J.E., Klosko, J.S. ve Weishaar, E.M. (2003). Şema Terapi (T.V. Soylu, Çev.). İstanbul: Litera Yayıncilik.

ETİK ve BİLIMSEL İLKELER SORUMLULUK BEYANI

$\mathrm{Bu}$ çalışmanın tüm hazırlanma süreçlerinde etik kurallara ve bilimsel atıf gösterme ilkelerine riayet edildiğini yazar(lar) beyan eder. Aksi bir durumun tespiti halinde Afyon Kocatepe Üniversitesi Sosyal Bilimler Dergisi'nin hiçbir sorumluluğu olmayıp, tüm sorumluluk makale yazarlarına aittir. 